\title{
Taxonomic redescription of the Portuguese man-of-war, Physalia physalis (Cnidaria, Hydrozoa, Siphonophorae, Cystonectae) from Brazil
}

\author{
Juliana Bardi \& Antonio C. Marques
}

Departamento de Zoologia, Instituto de Biociências, USP, Caixa Postal 11461, 05422-970 São Paulo, SP, Brasil. (bardibio@yahoo.com.br; marques@ib.usp.br)

\begin{abstract}
Although Physalia physalis (Linnaeus, 1758) is widely known from the Brazilian waters, specimens from this coast were never properly described. We describe Brazilian specimens of $P$. physalis including information on morphology, cnidome, SEM, and histological studies. Taxonomical issues concerning the development of the colonies and eventual synonymy with Physalia utriculus (La Martinière, 1787) are also added.
\end{abstract}

KEYWORDS. Cnidarian, hydrozoan, siphonophore, pleuston, systematics.

RESUMO. Redescrição taxonômica da caravela-do-mar, Physalia physalis (Cnidaria, Hydrozoa, Siphonophorae, Cystonectae) do litoral do Brasil. Physalia physalis (Linnaeus, 1758) é amplamente conhecida em águas brasileiras, mas os espécimes dessa costa nunca foram formalmente descritos. Descrevem-se os espécimes brasileiros, adicionando-se informações sobre a morfologia, cnidoma, MEV e histologia. Questões taxonômicas que envolvem o desenvolvimento das colônias e a eventual sinonímia com Physalia utriculus (La Martinière, 1787) também são abordadas.

PALAVRAS-CHAVE. Cnidário, hidrozoário, sifonóforo, plêuston, sistemática.

Siphonophores are highly polymorphic pelagic cnidarians, including both polyps and medusae, already proposed as superorganisms (MACKIE, 1963). The group is nested among other polymorphic cnidarians, such as Anthoathecata and Leptothecata (MARques \& Collins, 2004; Collins et al., 2006; VAN ItEN et al., 2006), in Hydroidolina. Siphonophore phylogeny was inferred based on nuclear small subunit ribosomal RNA gene (18S) and the mitochondrial large subunit ribosomal RNA gene (16S) (Dunn et al., 2005). The subclass traditionally includes three orders (KIRKPATRICK \& PUGH, 1984), although recently one of these orders was found nonmonophyletic. Cystonectae would be the basal clade, and sister-group of the recent proposed Codonophora, i.e., Calycophorae nested within the Physonects (Collins, 2000; DunN et al., 2005).

The monophyletic Cystonectae is defined by the presence of a pneumatophore and siphosome and lack of nectosomal nectophores (DunN et al., 2005). The group encompasses only two families, Physaliidae and Rhizophysidae. The pleustonic colonies of Physaliidae are represented by the well known Portuguese man-ofwar, Physalia physalis (Linnaeus, 1758), that is easily distinguished by the presence of an enlarged pneumatophore, a sail-shaped, bluish-pinkish structure filled with gas produced by a gas gland. The colonies bear three types of medusoids - gonophores, siphosomal nectophores and vestigial siphosomal nectophores and four types of polypoids - free gastrozooids, gastrozooids with tentacles, gonozooids and gonopalpons (TоттоN, 1960). Both polypoid and medusoid organisms are grouped into cormidia located in the lower/inferior region of the pneumatophore.

Colonies of $P$. physalis are dioecious. Gametes are spawned in the water and fertilization is external (PuGH,
1999). The planula is formed after gastrulation, as in most cnidarians (CARRÉ \& CARRÉ, 1994). Tentacles are long, bearing numerous nematocysts (CORMIER \& HESSINGER, 1981), used for defense and prey capture. The main proteinaceous component of its venom is the "physaliatoxin", a powerful hemolysin (TAMKUN \& Hessinger, 1981). The Portuguese man-of-war feed on squids and fishes (both adults and larvae), and heavily infestation of this species may decrease fisheries (Purcell, 1984).

Physalia physalis is common in tropical and subtropical regions of the oceans (KIRKPATRICK \& Pugh, 1984), ranging from $55^{\circ} \mathrm{N}$ to $40^{\circ} \mathrm{S}$. Colonies of this species were recorded along the whole Brazilian coast (MigOTTO et al., 2002). Although colonies have been long recorded, Brazilian colonies were never properly morphologically and histologically characterized. This paper presents the redescription of Physalia physalis for the Brazilian coast.

\section{MATERIAL AND METHODS}

We studied colonies of $P$. physalis from different locations of the Brazilian coast, totaling 77 colonies. The material is deposited in the Cnidarian Collection of the Museu de Zoologia of the Universidade de São Paulo (MZUSP), as records MZUSP 779 to MZUSP 790.

The taxonomic description focused on morphology and morphometry. Morphometrical parameters were taken for the different zooids and general aspects of the colony, viz. length and diameter of the pneumatophore, length of the tentacle, length and diameter of the gastrozooid, length and diameter of the dactylozooid, length of gonopalpons, diameter of gonophores, diameter of nectophores, diameter of gonodendron, diameter of gas glands, and number of wrinkles of the pneumatophore. 
Measures were taken using stereomicroscope. The cnidome terminology follows WEILL (1934) and MARISCAL (1974); the nematocysts of 15 fixed colonies from different locations were measured non-discharged.

Histological studies and scanning electron microscopy (SEM) were carried out to describe the gonodendron, tentacle, tentacle with dactylozooid and gastrozooid of colonies of two distant sites, São Sebastião (SP) and Paripuera (AL). Colonies for SEM were fixed in a $10 \%$ formalin solution and post-fixed in $1 \% \mathrm{OsO}_{4}$, de-hydrated in an ethanol series, dried in their critical point and sputtered with gold (MigotTo \& Marques, 1999). Histological studies used routine methods of Mallory trichromic (BEHMER et al., 1976).

There are multiple implicit terminologies used to describe the morphology of siphonophores, which makes the nomenclature conflicting (HADDOCK et al., 2005; DunN \& Wagner, 2006). TоттоN (1960) demonstrated that features of the budding process of mature $P$. physalis colonies are highly derived and fundamentally different than any other siphonophore, including other cystonects. Therefore, whenever necessary, we tried to specify our usage of terms to describe Physalia physalis.

Physalia physalis has zooids arranged in clusters attached to the colony, called 'cormidia' (TоттоN, 1960). Although homonymic, the cormidia of Physalia are not necessarily homologous to the cormidia of other species of cystonects (DunN \& WAGNER, 2006). The cormidia are formed by many tripartite groups, that contain a gastrozooid, a gonodendron and an ampullae [viz., modified and hypertrophied portion of a gastrozooid lacking the oral opening (ТоттоN, 1960), herein denominated dactylozooid] with a tentacle.

Concerning topographical orientation, the terms 'proximal' and 'distal' are used herein to describe the relative positions of features along the structures attached to the colony, with proximal meaning closer to the attachment point (cf. HADDOCK et al., 2005).

\section{RESULTS}

\section{Physalia physalis (Linnaeus, 1758) \\ (Figs. 1-36)}

Holothuria physalis Linnaeus, 1758:823.

Physalia arethusa L. Agassiz, 1862:335 (pl. XXXV, fig. 1).

Physalia physalis Totton, 1960:301 et seq. (pl. IX, fig.1); TоттоN, 1965:39-40 (pl. I, fig. 1); KirkPatrick \& Pugh, 1984:26-27 (fig. 5); PAGÈs et al., 1992:68 (fig. 1).

Material examinado. BRASIL, Ceará: Fleixeiras, 2 colonies, 03.XI.2002, I. X. Martins col. (MZUSP 779); Rio Grande do Norte: Natal, 2 colonies, 29.XII.1998, F. L. da Silveira col. (MZUSP 780); Tibaú, 1 colony, 01.VII.2003, H. Matthews-Cascon col. (MZUSP 781); Alagoas: Paripuera (Urbana Beach), 32 colonies, 26.VI.2002, F. L. da Silveira col. (MZUSP 782); Bahia: Salvador (Flamengo Beach), 5 colonies, 09.I.2004, D. Ascher col. (MZUSP 783); Rio de Janeiro: Arraial do Cabo (Prainha), 18 colonies, 16.X.1998, F. L. da Silveira col. (MZUSP 784); São Paulo: São Sebastião, 1 colony, 20.V.1997, A. C. Mota col. (MZUSP 785); 2 colonies, 03.XI.2003, O. M. P. Oliveira col. (MZUSP 786); 2 colonies, 03.XI.2003, O. M. P. Oliveira col. (MZUSP 787); Guarujá (Pitangueiras): 9 colonies, 31.XII.2003, S. N. Stampar col. (MZUSP 788); 1 colony, 31.XII.2003, S. N. Stampar col. (MZUSP 789); Ilha Comprida: 2 colonies, 11.XI.1999, A. C. Morandini col. (MZUSP 790).
Description. Colonies with triangular pneumatophore, 8.1-134 mm in length, maximum diameter 3.6-65.1 mm, formed by thin pink-bluish membrane (Fig. 1). Pneumatophore with 5-29 wrinkles at upper region. Apical pore in the aboral region of the colony. Gas gland 0.9-36.4 mm in diameter. Oral and main zones of colony separated by basal internode, a gap region with no polyps. Main zone more developed than oral zone. Polymorphic organisms organized in cormidia, budding off from basal/inferior region of pneumatophore. Oral zone with up to five cormidia and protozooid (= first gastrozooid). Main zone with up to seven cormidia. Cormidia of main zone formed by zooid groups, with different composition and development in different organisms: 1) 'reduced group', consisting of gastrozooids; 2) 'primary tripartite group', consisting of gastrozooid, tentacle with dactylozooid and

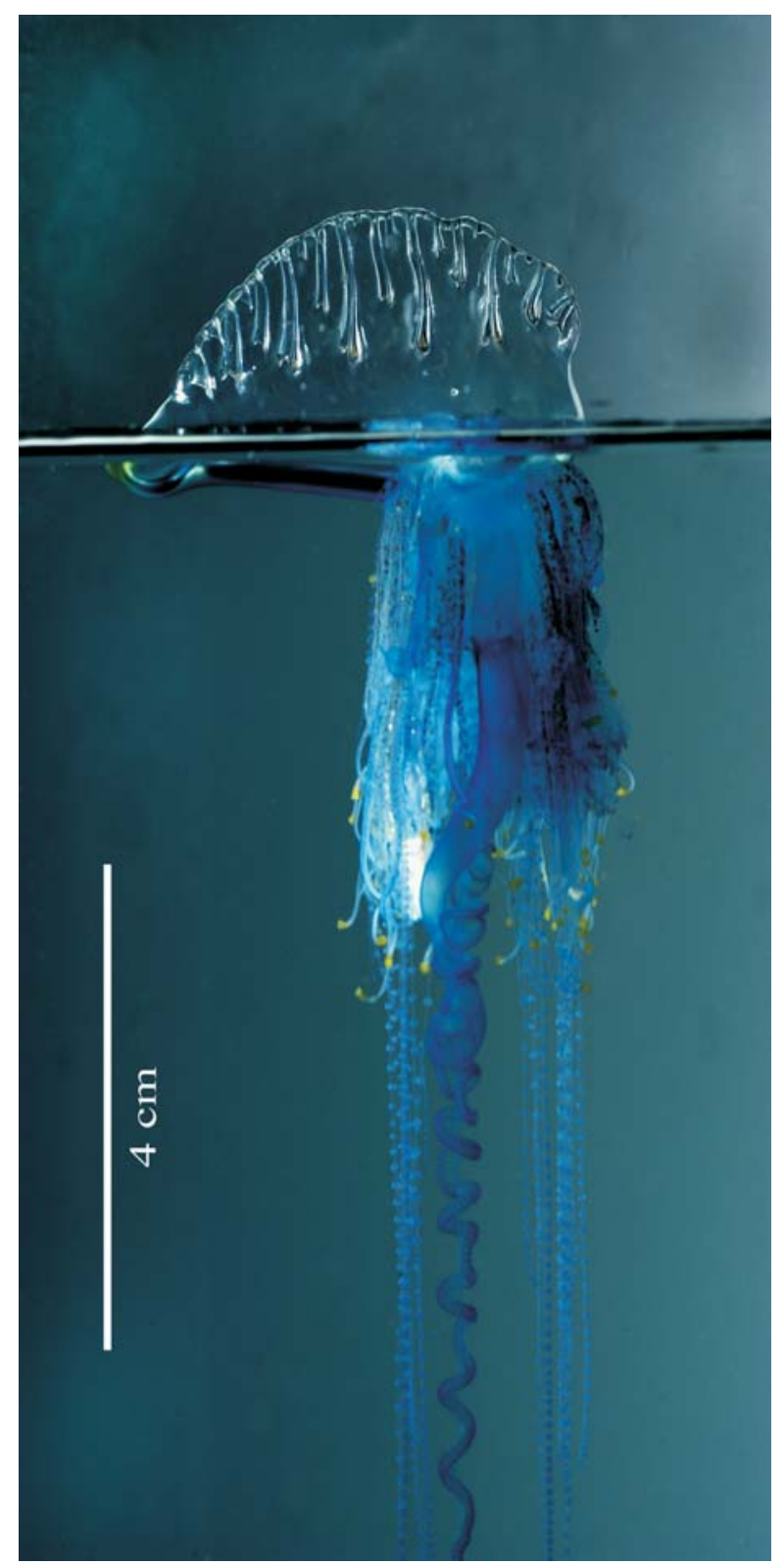

Fig. 1. Colony of Physalia physalis (Linnaeus, 1758). Photograph by A. E. Migotto. 


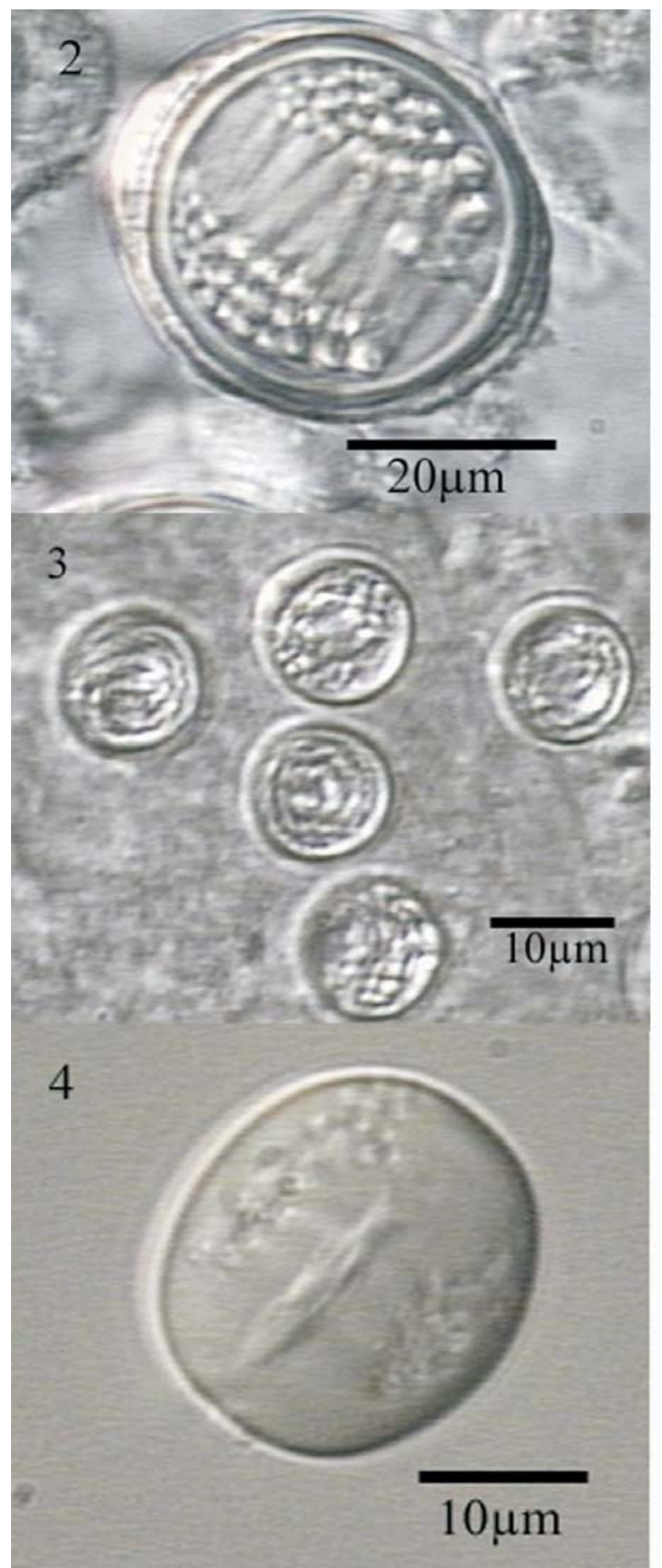

Figs. 2-4. Nematocysts of Physalia physalis (Linnaeus, 1758): 2, big isorhiza; 3, small isorhiza; 4, stenotele.

gonodendron; 3) 'lateral groups', trifid, budding off from branches of the 'primary tripartite group'; 4) 'secondary basal buds', trifid, budding off from base of "reduced", "primary tripartite" or "lateral" groups. Cormidia of oral zone without "primary tripartite group". Dioecious colonies. Gonodendra branched; branches with male or female gonophores (Fig. 5). Subterminal branch end with elongated vestigial nectophore (Fig. 6) and elongated tubular gonopalpon. Terminal branch end with nectophore and gonopalpon (Fig. 7). Gonodendron main branch base 0.3-2.4 $\mathrm{mm}$ in diameter. Gonophores ovoid
(Fig. 8), largest diameter 0.08-0.75 mm. Elongated nectophores with widened distal end, bell-shaped, larger diameter 0.24-1.125 mm (Fig. 9). Gonopalpons 0.11-5.6 mm in length (Fig. 10), concentrated at distal ends of the subterminal and terminal branches. Elongated gastrozooids distally widening from median region, with subterminal constriction and mouth at distal end (Fig. 11), either free or associated to dactylozooid; largest diameter of gastrozooids $0.25-3.375 \mathrm{~mm}, 0.7-1.3 \mathrm{~mm}$ in length. Elongated dactylozooid with thinner distal end, 0.6-32.2 $\mathrm{mm}$ in length, largest diameter 0.2-6.25 $\mathrm{mm}$. Larger dactylozooids linked to tentacles along its whole length, smaller ones partially and basally linked to tentacles. Tentacles compressed, 5.3-468.9 mm in length, smaller tentacles sinuous along its length, larger tentacles curly from median to distal region (Fig. 12). Nematocyst batteries concentrated in thicker regions of tentacles, spirally arranged (Fig. 13).

Two morphological types of nematocysts seen: isorhiza (two size classes) and stenoteles (one size class). Isorhiza, large (Fig. 2) spherical, not seen discharged, 17.54-47.77 x 17.68-45.16 mm $(\mathrm{n}=404)$, present on tentacles, dactylozooids, gastrozooids, gonopalpons. Isorhizas, small (Fig. 3) spherical, not seen discharged, 7.95-14.39 x 8.46-14.92 mm ( $\mathrm{n}=348)$, present on tentacles, dactylozooids, gastrozooids. Stenoteles (Fig. 4) not seen discharged, 11.69-24.69 x 11.17-25.45 mm ( $\mathrm{n}=205)$, present on dactylozooids, gastrozooids, gonopalpons.

Variation observed in some colonies. Colonies from Paripuera, Salvador, Rio de Janeiro, and Ilha Comprida with one tentacle and one dactylozooid in the central portion of the colony, larger than the other polyps. Colonies from these regions with length of pneumatophore ranging from $8.1 \mathrm{~mm}$ to $82.1 \mathrm{~mm}$, mean length $20.4 \mathrm{~mm}$; colonies from Tibaú, Natal, Flexeiras, São Sebastião, Guarujá, that have several large tentacles, with length of pneumatophore ranging from $27.4 \mathrm{~mm}$ to $134 \mathrm{~mm}$, mean length $67.95 \mathrm{~mm}$. Colonies from Ilha Comprida and São Sebastião with few developed or no tentacles at oral end. Colonies from Natal with isorhiza nematocysts in three size classes: 'large' (27.12-32.15 x 31.16-31.54 mm) (n= 57), 'medium' (19.54-23.05 x 19.9-21.14mm) $(\mathrm{n}=23)$ and 'small' (9.41-12.26 x 9.83-11.54 mm) $(\mathrm{n}=93)$ "Large" and "medium" size classes are encompassed in the general definition of "large isorhiza" given in the general description above. Colonies from Ceará and Rio de Janeiro do not have stenoteles on dactylozooids.

Histology. Tentacles with hollow axis (cross section) with thick mesoglea (blue and acidophilous, as in all other zooids), inner gastrodermal and outer epidermal linings. Several mesogleal lamellae longitudinally arranged along "tentacular axis" region, completely surrounding it (Figs. $14,15)$. Tentacle with region with nematocyst batteries (Fig. 16). Epidermis of "nematocyst batteries" region formed by cubic cells, many cnidae with well visible nematocysts stained in pink or orange (Fig. 17). Gastrodermis of anterior region lining nematocyst batteries similar to the "tentacular axis" region, formed by cubic cells with grayish nuclei located at the cell basal region, apparently with secretion granules with yellowish content. Epidermis of "tentacular axis" region formed by red epitheliomuscular cells (Fig. 15). Fibers of 


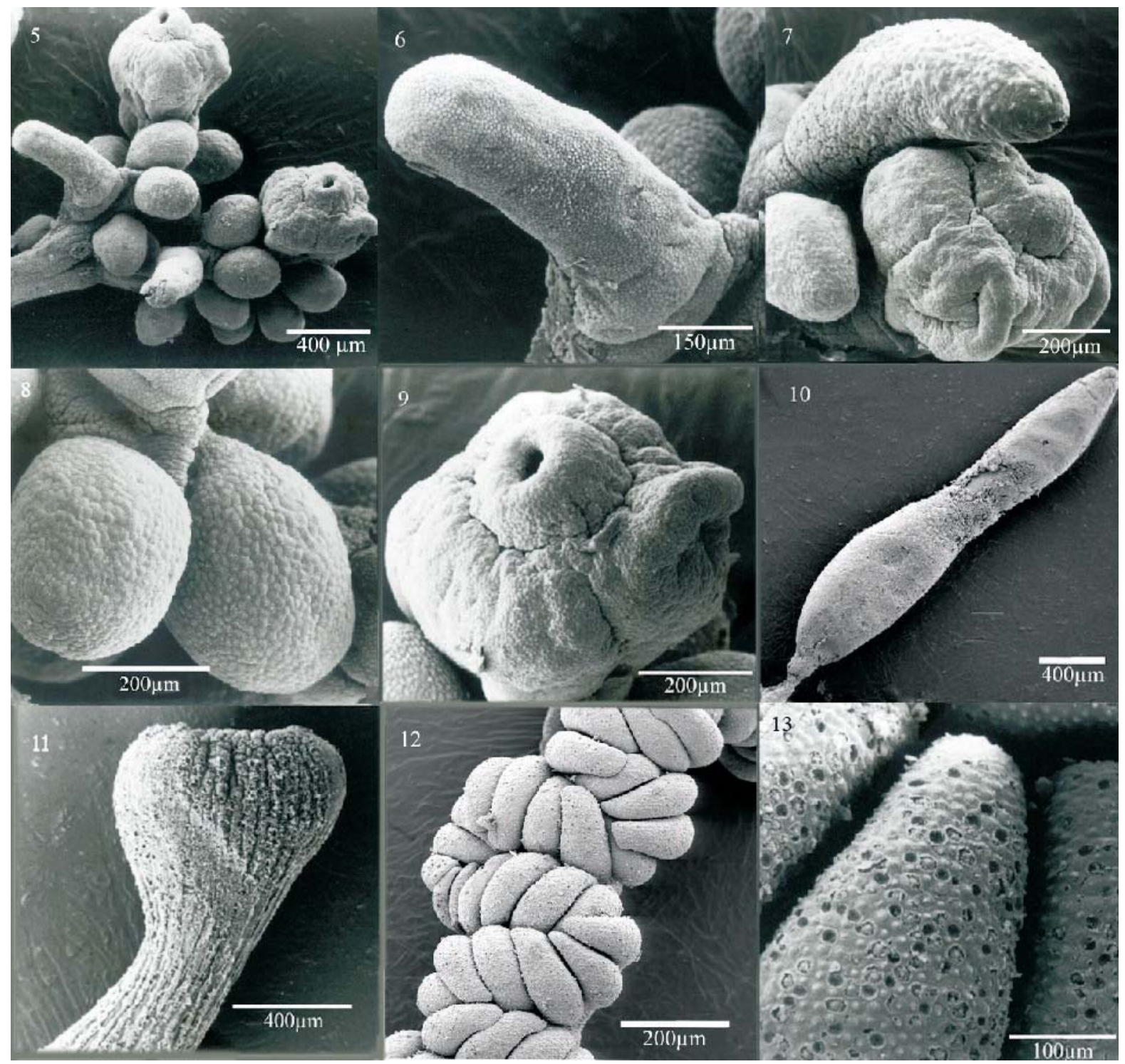

Figs. 5-13. Scanning electron microscopy (SEM) of Physalia physalis (Linnaeus, 1758): 5, branch of gonodendron with two nectophores, one vestigial nectophore and several gonophores (MZUSP 782); 6, detail of vestigial nectophore (MZUSP 782); 7, terminal end of gonodendron: gonopalpon (above) and nectophore (below) (MZUSP 782); 8, gonophores; (MZUSP 782); 9, detail of the distal portion of nectophore (MZUSP 782); 10, gonopalpon (MZUSP 785); 11, oral part of gastrozooid (MZUSP 785); 12-13, tentacle: 12, region with nematocyst batteries (MZUSP 782); 13, detail of nematocyst batteries (MZUSP 785)

epitheliomuscular cells longitudinally arranged along mesogleal lamellae.

Base of tentacles/dactylozooids thick (Fig. 18). Epidermis and gastrodermis formed by cubic cells. Thick mesoglea with centrifugal narrow and short outgrowths towards gastrovascular cavity. Tentacle and dactylozooid proximally linked, with common cavity lined by continuous gastrodermis, though clearly different in the transition tentacle/dactylozooid (Fig. 19). Gastrodermis of dactylozooid formed by columnar gland cells with acidophilous granular secretion stained in orange/yellow, cells organized in crests towards interior of gastrovascular cavity (Fig. 20). Tentacular gastrodermis formed by cubic cells with pinkish cytoplasm (acidophilous), with scarce of no secretion (Fig. 21). Tentacular epidermis (Fig. 21) with vacuolated cells, with few nematocysts stained in orange; epidermis of dactylozooid formed by columnar cells, nucleus at central region and granules with acidophilous secretions (Fig. 20). Tentacle and dactylozooid gradually separated distally, forming two cavities separated by mesogleal lamella lined by gastrodermis at both sides (Figs. 22, 23). Distal end of dactylozooid completely separated from tentacle.

Gastrozooid divided into aboral (basigaster) and oral regions, with different appearance of the gastrodermis. Epidermis of aboral region formed by epitheliomuscular fibers, longitudinally arranged at aboral-oral axis of gastrozooid, with few cnidae. Pinkish epitheliomuscular cells. Mesoglea thin with centrifugal narrow and small outgrowths, some longer and thicker outgrowths lined by gastrodermis with villi (Fig. 24) towards gastrovascular cavity. Cells of apical region with villi and brownish digestive vacuoles (filled with digestion products), nucleus and cytoplasm displaced to peripheral regions (Fig. 25). Cubic cells with grayish nucleus among villi, pinkish cytoplasm and few blue secretion granules 


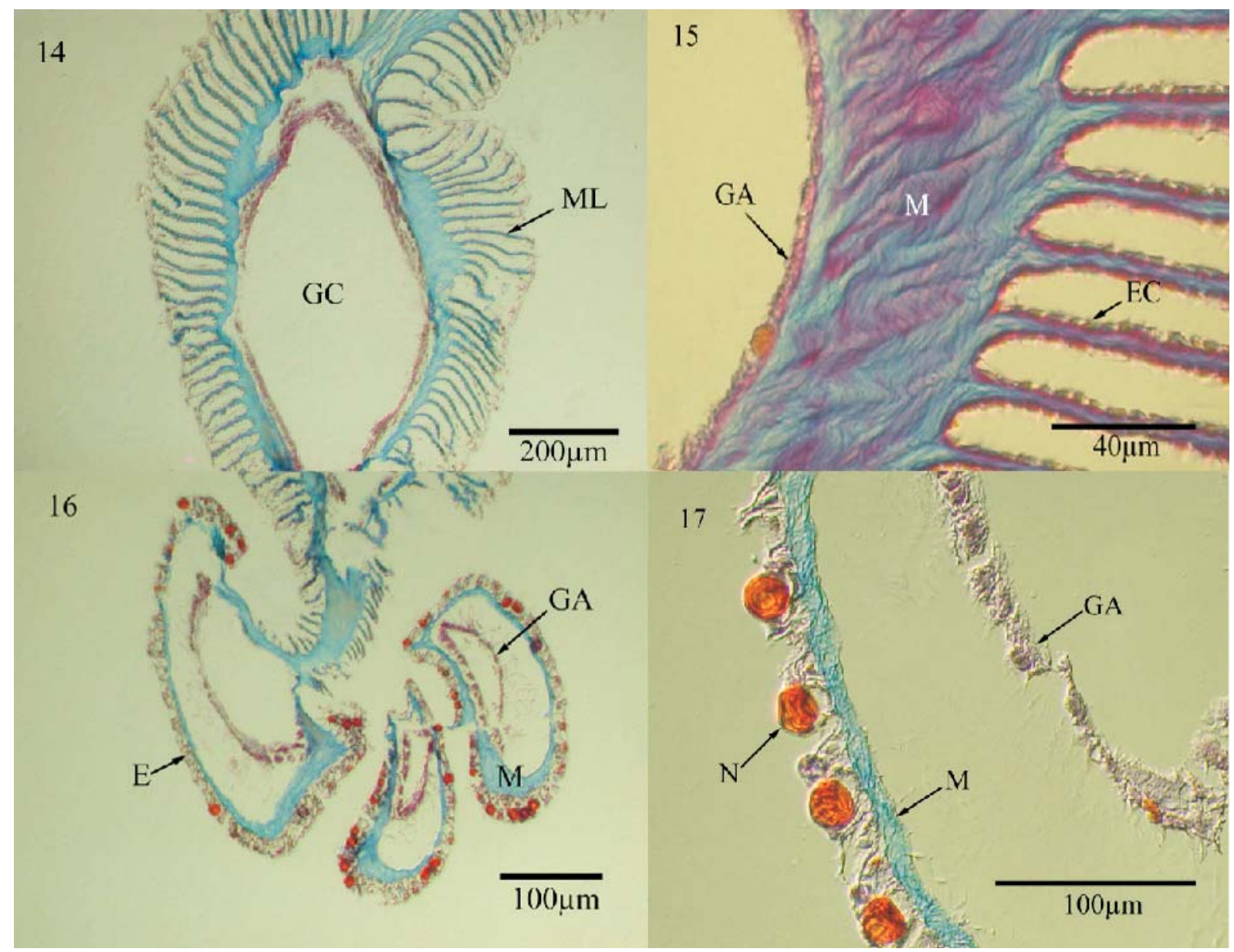

Figs. 14-17. Physalia physalis (Linnaeus, 1758), histology of tentacle, cross sections: 14, "tentacular axis" region showing gastrovascular cavity and mesogleal lamellae; 15, detail of the "tentacular axis" region; 16, "nematocyst batteries" region; 17, details of "nematocyst batteries" region. The gastrodermis is detached from the mesoglea (MZUSP 785). (E, epidermis; EC, epitheliomuscular cell; GA, gastrodermis; GC, gastrovascular cavity; M, mesoglea; ML, mesogleal lamellae; N, nematocysts).

(Fig. 24). Epidermis of oral region similar to that of aboral region, but with more cnidae. Mesoglea with narrow and small centrifugal outgrowths covered by epidermal cells; mesoglea with no outgrowths towards gastrovascular cavity, but gastrodermal cells forming outgrowths towards gastrovascular cavity (Fig. 26). Oral region with secreting cells including violet to pink granules at apical part of cytoplasm (Figs. 26, 27)

Gonodendron formed by several zooids. Basal part with epidermis formed by acidophilous pinkish squamous cells. Thin mesoglea. Gastrodermis artifactually detached from mesoglea, as a solid branch with large cells, acidophilous red nuclei, small cytoplasmic vacuoles (Fig. 28).

External part of the gonophores composed by two layers of squamous epidermic cells separated by thin mesoglea; spadix (modified manubrium of medusae) surrounding by "gonads". Canal between mesogleal lamella and epidermis, probably related to reduction of subumbrellar cavity (Fig. 29). Germ cells form layer of cubic, acidophilous cells with prominent dark red nuclei (Fig. 30). Layer of germ cells lining spadix, gastrodermal cells with pinkish acidophilous cytoplasm with orange secretions that may form villi towards gastrovascular cavity (Fig. 30). Layer of acidophilous fibers between germ cells and spadix.
Gonopalpon with epidermis formed by pinkish cubic cells with acidophilous secretions and few blue or orange cnidae. Gastrodermis formed by cubic cells, cytoplasm with acidophilous secretion vacuoles (Figs. 31,32 ). Distal portion of gonopalpon with mesoglea outgrowths towards gastrovascular cavity and lined by gastrodermic cells, forming villi (Fig. 33) similar to those of aboral region of gastrozooid. Cells of apical region of the villi with large brownish digestive vacuoles (products of digestion). Some cells of the villi with cytoplasmic pinkish and orange secretions.

Nectophore proximal region with epidermis formed by tall columnar cells, with yellow to orange acidophilous secretions at apical region. Mesoglea thin. Gastrodermis seems not well preserved, with cubic cells with acidophilous secretions (Fig. 34). Distal region with epidermis similar to that of proximal region. Gastrovascular cavity lined by gastrodermis at distal region. Cubic cells in gastrodermis with reddish acidophilous secretions. Epitheliomuscular cells not observed in this zooid (Fig. 35).

Vestigial nectophore with similar histology of nectophoral proximal region. Epidermis formed by tall columnar cells, pale pink cytoplasm, elongated grayish nuclei at cell center. Yellow to orange acidophilous secretions at apical portion of cell. Gastrodermis formed 


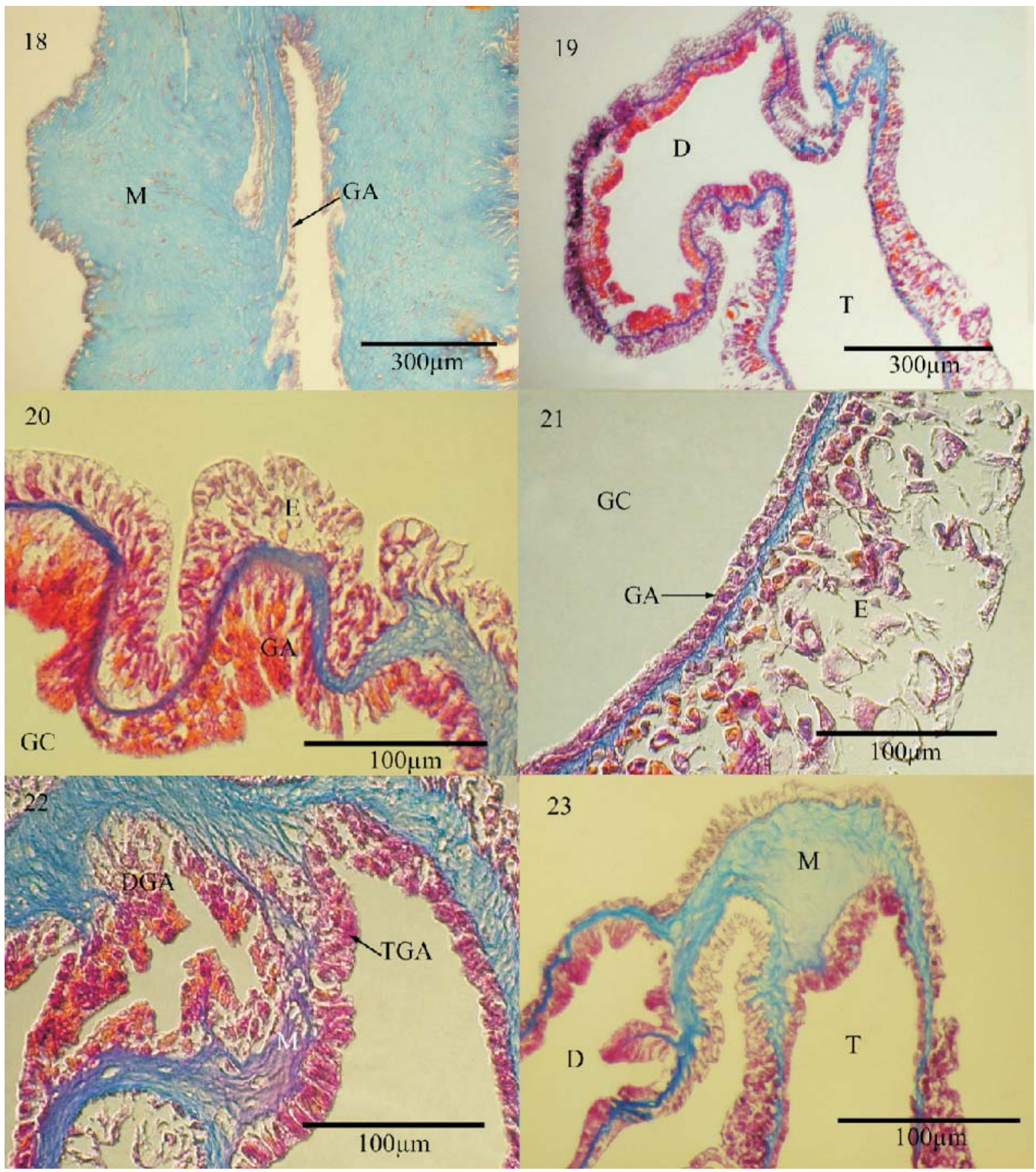

Figs. 18-23. Physalia physalis (Linnaeus, 1758), histology of tentacles and dactylozooids, cross sections: 18, common base of tentacle and dactylozooid; 19, proximal region of the tentacle and dactylozooid showing the common gastrovascular cavity; 20, dactylozooid wall; 21, tentacular wall. Gastrodermis formed by cubic cells. Epidermis with vacuolated cells; 22, median/distal portion of tentacle and dactylozooid, showing the separation of these zooids; 23, distal portion of tentacle and dactylozooid, showing the separation of gastrovascular cavity by a mesogleal layer (MZUSP 782). (D, dactylozooid; DGA, dactylozooid gastrodermis; E, epidermis; GA, gastrodermis; GC, gastrovascular cavity; M, mesoglea; T, tentacle; TGA, tentacular gastrodermis).

by cubic cells, pinkish acidophilous cytoplasm, grayish nuclei displaced toward base of cell (Fig. 36).

\section{DISCUSSION AND CONCLUSIONS}

Morphology and taxonomy. Colonies of Physalia may be divided in the main and oral zones (TotTon, 1960). Polyps, organized in cormidia, are arranged differently in both zones. The separation of the cormidia is easily noticed, but the identification of the different groups described above is facilitated when following the development of the colony. Therefore, subjects like the actual branching structure of gonodendra and the budding sequence that gives rise to the tripartite groups are still open questions for future studies. Some evolutionary implications of the study of siphonophore development may be seen in DunN \& WAGNER (2006). 


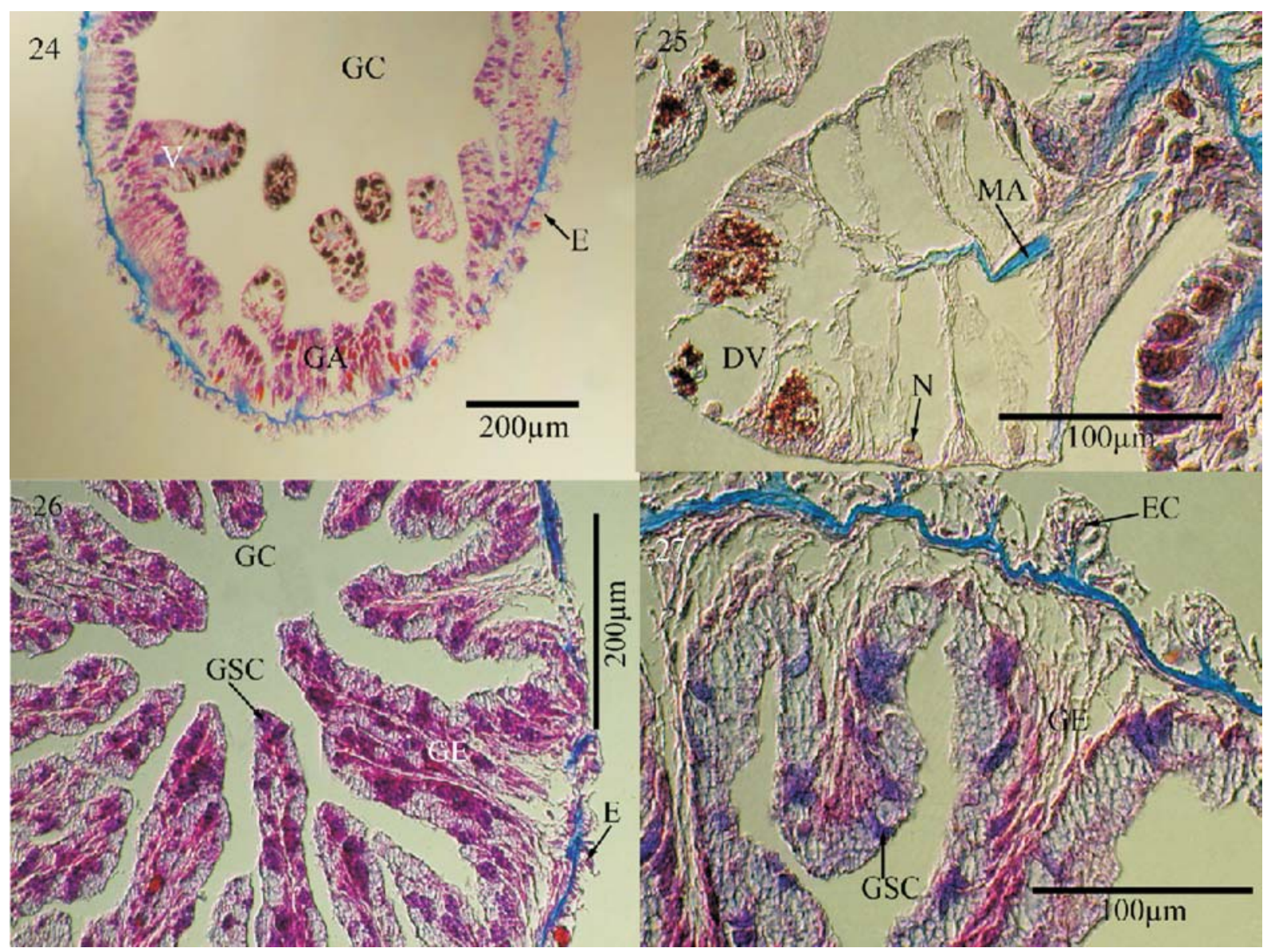

Figs. 24-27. Physalia physalis (Linnaeus, 1758), cross section of the gastrozooid. 24-25, aboral region: 25, detail of a villus with the mesogleal axis and cells with digestive vacuoles; 26, oral region; 27, secreting cells with less secretion than those of the figure 26 (MZUSP 782, MZUSP 785). (DV, digestive vacuole; E, epidermis; EC, epitheliomuscular cell; GA, gastrodermis; GC, gastrovascular cavity; GE, gastrodermic evagination; GSC, gastrodermic secreting cell; MA, mesoglea axis; N, nucleus; V, villus).

Some particularities may be highlighted for the Brazilian colonies. The colonies from Ilha Comprida and São Sebastião have no or few developed tentacles in the oral zone. However, the cormidia of the oral zone do not bear the tripartite primary group; cormidia 1 and 2 bear lateral buds, and cormidium 1 bears also basal buds (TоттоN, 1960). This justifies the lack of tentacles in the oral zone, because the larger tentacles are those of the tripartite primary group. On the other hand, colonies from Paripuera, Rio de Janeiro and Ilha Comprida bear well developed tentacle and dactylozooid, occupying a central position in the main axis of the colony.

Tentacular development was already used in the taxonomy of the genus. Comparisons between Atlantic and Pacific colonies supported the hypotheses of two different species in the genus Physalia (CHUN, 1897; Bigelow, 1911, 1919; FenNER et al., 1993), differing by the presence of a unique main tentacle [Pacific Ocean, corresponding to Physalia utriculus (La Martinière, 1787)] or several large tentacles [Atlantic Ocean, corresponding to $P$. physalis (Linnaeus, 1758)]. Nevertheless, according to TоттоN (1960), the number of large tentacles increases during the development of $P$. physalis, which justifies some authors considering the genus monotypic (e.g. TоттоN, 1960). In fact, the colonies we studied with more than one well developed tentacle are longer in the length of pneumatophore, which would corroborate with TOTTON (1960). Another possibility of classification considers $P$. utriculus a "variety" of $P$. physalis (e.g. TокіокA, 1973), what seems biologically meaningless.

All colonies presented two kinds of nematocysts, isorhiza and stenoteles. Literature data on cnidome is, however, divergent. ClausEN (1967) described five types of nematocysts for $P$. physalis: isorhiza, stenoteles, euryteles, desmonemes, and mastigophores. GOLDBERG $\&$ TAYLOR (1997) studied the tentacles of $P$. physalis and described two sizes classes of isorhiza nematocysts. WeILl (1934), on the other hand, described stenoteles and isorhiza for Physalia arethusa (L. Agassiz, 1862), first species of the genus described for the American continent, presently considered a junior synonym of $P$. physalis. YANAGIHARA et al. (2002) described the cnidome of $P$. utriculus as composed by heterotrichous anisorhiza and rare rhopaloids. The differences of cnidome between $P$. utriculus and $P$. physalis would support the existence of both species, but we did not studed Pacific materials to corroborate the presumptive cnidome.

Functionally, isorhizas are concentrated in the tentacular batteries, related to the food capture (PURCELL, 1984) and protection of the colony. No colony has nematocysts on the gonophores. The lack of nematocysts 


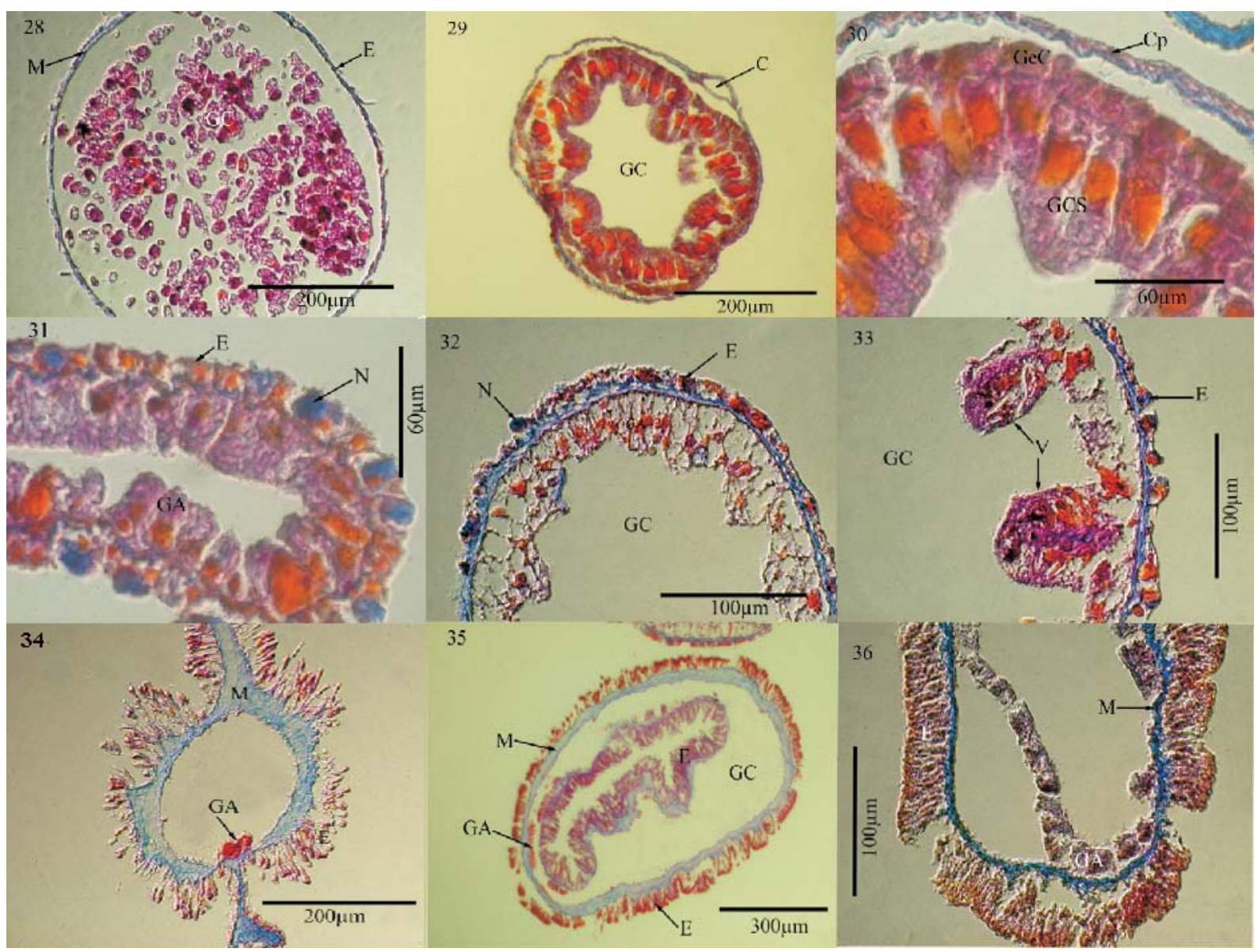

Figs. 28-36. Physalia physalis (Linnaeus, 1758), histology of the gonodendron, cross sections. 28, base of gonodendron (MZUSP 785); 29-30, gonophore, in 30 a detail of the wall of gonophore (MZUSP 782); 31, gonopalpon (MZUSP 782); 32, proximal region of gonopalpon; gastrodermic cells with little secretion in the cytoplasm (MZUSP 785); 33, distal region of the gonopalpon, showing detail of the villi formed by mesoglea and gastrodermis (MZUSP 785); 34-35, nectophore: 34, proximal region with badly preserved gastrodermis; 35, distal region (MZUSP 785); 36, vestigial nectophore; part of the gastrodermis artifactually detached from the mesoglea. (C, canal; Cp, capsule-epidermis and mesoglea; E, epidermis; GA, gastrodermis; GC, gastrovascular cavity; GCS, gastrodermic cells of the spadix; $\mathrm{GeC}$, germ cells; $\mathrm{M}$, mesoglea; $\mathrm{N}$, nematocyst; V, villus).

on the gonophores and presence on the gonopalpons demonstrates the defensive function of this zooid in the gonodendron.

Histology. As stated by MACKIE (1960), epitheliomuscular cells of epidermic origin occur in the tentacles (Fig. 15) and gastrozooids (Fig. 27) The way epitheliomuscular fibers are arranged and supported by mesogleal lamella (Figs. 14, 15) indicates that the muscular system is the responsible for the movement of stretching and retraction of these zooids, a function corroborated by us. Therefore, the presence of epitheliomuscular cells allows movements to capture prey, and are commonly associated with a thicker mesoglea (in the tentacle). The epitheliomuscular fibers of the gastrodermis are fewer developed (MACKIE, 1960), and we were not able to characterize them.

We did not observe epitheliomuscular cells in the nectophore. MACKIE (1960) stated that the lack of epitheliomuscular cells in the nectophore demonstrates that this structure is not functional for locomotion in the colony. In fact, some authors do not consider the nectophores of Physalia as true nectophores. In a recent paper, Dunn et al. (2005) considered that "these siphosomal nectophores can sometimes look quite similar to the medusae specialized for sexual reproduction, and it may be that propulsive medusae (which are not found to be retained in the colonies of any other hydrozoans) are derived from retained reproductive medusae. The siphosomal nectophores are not well understood, though, and too few data are available to make a survey of them". However, the gelatinous mesoglea of nectophores and vestigial nectophores may contribute for the buoyancy of the colony (MACKIE, 1960).

The oral region of the gastrozooid promotes the extracellular digestion with its gland cells liberating enzymes (MACKIE, 1960). In fact, we observed gland cells full of secretions forming the gastrodermis of the oral region (Figs. 26, 27). On the other hand, the large vacuoles of the aboral region of the gastrozooids (Figs. 24, 25) are related to the engulfing process, consequently promoting intracellular digestion. Besides, the presence of villi in the distal region of gonopalpons (Fig. 33), similar to those found in the aboral region of gastrozooids, suggests that gonopalpons may also be involved in the digestive process (MACKIE, 1960). 
Nectophores were already misunderstood as gonophores (e.g. HAECKEL, 1888), and the distinction between both zooids, as well as the distinction between male and female gonophores, was first established by STECHE (1907). The gonophores may be distinguished by their morphology: male gonophore is formed by a spadix with thin walls, lined by a thick layer of germ cells; female gonophores are formed by a spadix with thick walls, lined by a thin layer of germ cells (MACKIE, 1960). However, it was not possible to distinguish between male and female gonophores in our observations.

Acknowledgments. This manuscript was part of the undergraduate studies of JB. The authors thank A. C. Morandini (NUPEM/UFRJ), F. L. da Silveira (IB/USP), T. M. Lotufo (UFCE), and H. Matthews-Cascon (UFCE) for donating material, E. Mattos (IB/USP, São Paulo) for helping us in SEM and histological procedures, V. B. Tronolone (IB/USP) and V. Shimabukuro (IB/USP) for suggestions during the development of this study, G. O. Mackie (University of Alberta) for references, C. Dunn (Yale University, USA) for commenting on a previous version of the manuscript and CEBIMar-USP for collecting materials. The study had financial support from CNPq (302596/2003-8 and 471960/2004-7 to ACM); PROBio (Brazilian Ministry of Environment); and FAPESP (Proc. 2003/01262-7, 2004/09961-4, 2006/55591-0).

\section{REFERENCES}

Agassiz, L. 1862. Discophorae. Contributions to the Natural History of the United States of America 5(3):3-380, pl. 20-35

Behmer, O. A.; Tolosa, E. M. C. \& Freitas Neto, A. G. 1976. Manual de técnicas para Histologia normal e patológica. São Paulo, EDART. 241p.

Bigelow, H. B. 1911. The Siphonophorae. Reports of the Scientific research expedition to the tropical Pacific Albatross XXIII Memoirs of the Museum of Comparative Zoology at Harvard College 38:173-402.

1919. Hydromedusae, Siphonophores and Ctenophores of the "Albatross" Philippine expedition. Bulletin of the United States National Museum 1(5):279-362, pl. 39-42.

Carré, C. \& Carré, D. 1994. Ordre des Siphonophores. In: Boulllon, J. ed. Traité de Zoologie: Cnidaires et Cténaires. Paris, Masson. tome III, fascicule 2, p.525-596.

Chun, C. 1897. Histologie der Hydromedusen. In: Bronn, H. G. ed. Klassen und Ordnungen des Tierreichs, Zweiter Band, II Abteilung, p. 295-326.

Clausen, C. 1967. Morphological studies of Halammohydra remanei (Hydrozoa). Sarsia 29(1):349-370.

Collins, A. G. 2000. Towards understanding the phylogenetic history of Hydrozoa: hypothesis testing with $18 \mathrm{~S}$ gene sequence data. Scientia Marina 64 (Supl.1):5-22.

Collins, A. G.; Schuchert, P.; Maroues, A. C.; Jankowski, T.; Medina, M. \& Schierwater, B. 2006. Medusozoan phylogeny and character evolution clarified by new large and small subunit rDNA data and an assessment of the utility of phylogenetic mixture models. Systematic Biology 55(1):97-115.

Cormier, S. M. \& Hessinger, D. A. 1981. Cellular basis for tentacle adherence in Portuguese Man-of-War (Physalia physalis). Tissue and Cell 12(4):713-721.

Dunn, C. W. \& Wagner, G. P. 2006. The evolution of colonylevel development in the Siphonophora (Cnidaria:Hydrozoa). Development, Genes and Evolution 216(12):743-754.

Dunn, C. W.; Pugh, P. R. \& Haddock, S. H. D. 2005. Molecular phylogenetics of the Siphonophora (Cnidaria), with implications for the evolution of functional specialization. Systematic Biology 54(6):916-935.

Fenner, P. J; Williamson, J. A.; Burnett, J. W. \& Rifkin, J. 1993. A newly differentiated species of Physalia physalis in Australia. The Australian Medical Journal 158:500.
Goldberg, M. G. \& Taylor, G. T. 1997. Coelenterate cnidae capsules: disulfide linkages reveled by silver cytoschemistry and their differential responses to thiol reagentes. Biological Bulletin 192(1): 1-16

Haddock, S. H. D.; Dunn, C. W. \& Pugh, P. R. 2005. A re-examination of siphonophore terminology and morphology, applied to the description of two new prayine species with remarkable biooptical properties. Journal of the Marine Biological Association of the United Kingdom 85(3):695-707.

Haeckel, E. 1888. Report on the Siphonophorae. In: Murray, J. ed. Report on the Scientific results of the voyage of $\mathbf{H}$. M. S. Challenger. Edinburgh, Neill and Co. v.28, p.1-380. Kirkpatrick, P. A. \& Pugh, P. R. 1984. Siphonophores and Velellids. Synopses of the British Fauna New Series 29: 1 - 154 .

LinNAeus, C. 1758. Systema Naturae per regna tria Naturae, editio 10, London, British Museum (Natural History). 823p.

Mackie, G. O. 1960. Studies on Physalia physalis (L.). Part 2. Behavior and histology. Discovery Reports 30:371-407.

1963. Siphonophores, bud colonies, and superorganisms. In: Dougherty, E. C. ed. The lower Metazoa. Berkeley, University of California. p.329-337.

Mariscal, R. N. 1974. Nematocysts. In: Muscatine, E. L. \& Lenhoff, H. M. eds. Coelenterate Biology. Reviews and new perspectives. New York, Academic. p.129-178.

Marques, A. C. \& Collins, A. G. 2004. Cladistic analysis of Medusozoa and Cnidaria evolution. Invertebrate Biology 123(1):23-42

Migotto, A. E. \& Marques, A. C. 1999. Hydroid and medusa stages of the new species Ectopleura obypa (Cnidaria: Hydrozoa: Tubulariidae) from Brazil. Proceedings of the Biological Society of Washington 112(2):303-312.

Migotto, A. E.; Marques, A. C.; Morandini, A. C. \& Silveira, F. L. 2002. Checklist of the Cnidaria Medusozoa of Brazil. Biota Neotropica 2(1):1-35.

Pagès, F.; Gili, J. M. \& Boulllon, J. 1992. Siphonophores (Cnidaria, Hydrozoa) of the Benguela Current (southeastern Atlantic). Scientia Marina 56 (supl. 1):65-112.

Pugh, P. R. 1999. Siphonophorae. In: Boltovskoy, D. ed. South Atlantic Zooplankton. Leiden, Backhuys. p.467-511.

Purcell, J. E. 1984. Predation on fish larvae by Physalia physalis, the Portuguese Man-of-war. Marine Ecology Progress Series 19:189-191.

Steche, O. 1907. Die Genitalanlagen der Rhisophysalien. Zeitschrift für Wissenschaftliche Zoologie 86(1):134-171.

TAmkun, M. M. \& Hessinger, D. A. 1981. Isolation and partial characterization of the hemolytic and toxic protein from the nematocyst venom of the Portuguese Man-of-war, Physalia physalis. Biochimica et Biophysica Acta 667:87-98.

ToKioKA, T. 1973. Consideration on the segregation of right and left handed types in Physalia. Publications of the Seto Marine Biological Laboratory 20(570):141-144.

Totтon, A. K. 1960. Studies on Physalia physalis (L.). 1. Natural history and morphology. Discovery Reports 30:301-368. 1965. A synopsis of the Siphonophora. London, British Museum (Natural History). 230p., 40pl.

Van Iten, H.; Leme, J. M.; Simões, M. G.; Marques, A. C. \& Collins, A. G. 2006. Reassessment of the phylogenetic position of conulariids (?Vendian-Triassic) within the subphylum Medusozoa (Phylum Cnidaria). Journal of Systematic Paleontology 4(2):109-118.

Weill, R. 1934. Contribution à l'étude des cnidaires et de leurs nématocystes. I. Recherches sur les nématocystes (morphologie, physiologie, dévelopment). II. Le valeur taxonomique du cnidome. Travaux de la Station zoologique de Wimereux 11:1-701.

Yanagihara, A.A.; Kuroiwa, J. M. Y.; Oliver, L, L. \& Kunkel, D. D. 2002. The ultraestructure of nematocysts from the fishing tentacle of the Hawaiian bluebottle, Physalia utriculus (Cnidaria, Hydrozoa, Siphonaptera). Hydrobiologia 489(13):139-150. 